\title{
Root Canal Morphology of the Mandibular First Premolars in a Yucatecan Population Using Cone Beam Computed Tomography: An in vitro Study
}

\author{
Morfología del Conducto Radicular de Primeros Premolares Mandibulares en \\ una Población Yucateca Usando Tomografía Computarizada: Estudio in vitro
}

\author{
Elma María Vega-Lizama'; Vera Tiesler²; Julio Roberto Chi-Keb²; \\ Marco Ramírez-Salomón ${ }^{1}$; Armando Hernández-Mejía ${ }^{3}$ \& Andrea Cucina ${ }^{2}$
}

VEGA-LIZAMA, E. M.; TIESLER, V.; CHI-KEB, J. R.; RAMÍREZ-SALOMÓN, M.; HERNÁNDEZ-MEJÍA, A. \& CUCINA, A. Root canal morphology of the mandibular first premolars in a Yucatecan population using cone beam computed tomography: An in vitro study. Int. J. Morphol., 36(4):1216-1221, 2018.

SUMMARY: A successful endodontic treatment requires knowledge of the internal configuration of dental root canals. Most of the people who live in Yucatan are of Maya origin, characterized by a Mongoloid dental pattern. Because of their ethnicity, variations are expected. The purpose of this investigation is to assess the morphological characteristics and variability of this population. One hundred and five extracted first mandibular premolars of Mexican Maya population were analyzed; the sample was obtained from the Oral Surgery Clinic in the School of Dentistry at the Autonomous University of Yucatan with written informed consent. Analyses were performed by means of Cone Beam Computed Tomography. Vertucci's Type I was the most prevalent configuration with $51.4 \%$, but 41 cases $(39.1 \%)$ presented a radicular groove and a C-shaped canal configuration. Overall, we documented 1, 2, 3, and 4 root canals. Mandibular first premolars are very variable in the Yucatecan population. The variability and frequency of C-shape is similar to mandibular second molars confirming the importance of the ethnic background for the endodontic treatments.

KEY WORDS: C-shaped canal; Mandibular first premolar; Root canal morphology.

\section{INTRODUCTION}

The success of root canal treatment depends on the ability to make a thorough cleaning, shaping, and sealing. Thus, knowledge about root canal morphology is essential (Hargreaves \& Berman, 2016). However, many different variants in root canal morphology have been reported in populations including C-shape, extra roots, and fusion configurations. These can be characterized with tomography. The aim of this analysis is to assess the characteristics and the extent of variability of the root canal morphology in the Maya population from this region.

\section{MATERIAL AND METHOD}

The teeth were collected from patients who required extraction in the Oral Surgery Clinic at the School of Dentistry of at the Autonomous University of Yucatan
(UADY) (Merida, Mexico). The reasons for extractions were totally independent of this study. The Medical Ethics Committee of the UADY approved this study. Written informed consent was obtained from all patients, and a questionnaire was completed to report sex, age, and ethnic origin. One hundred and five teeth (according to sample size Epi Info) were obtained, which fulfilled the following criteria: 1. Signed consent. 2. Have at least one Maya last name and be born in Yucatan with parents and grandparents of Maya ethnicity. 3. Presence of a complete permanent mandibular first premolar. 4. Absence of root canal treatment, caries or restoration, root resorption or periapical lesions.

The teeth were cleaned of any soft-tissue remnants, disinfected with $2.5 \%$ sodium hypochlorite and an ultrasonic bath (NSK Varios 560 ® Japan). They were individually identified with a folio number and stored in an individual bag.

\footnotetext{
${ }^{1}$ Facultad de Odontología, Universidad Autónoma de Yucatán, Yucatán, México.

${ }^{2}$ Facultad de Ciencias Antropológicas, Universidad Autónoma de Yucatán, Yucatán, México.

${ }^{3}$ Centro Avanzado de Microscopía Endodóntica, Los Algodones, Baja California Norte. México.
} 
The Cone Beam Computed Tomography (CBCT) images were obtained using a CBCT scanner (Kodak Carestream $90003 \mathrm{D} \circledast$ Spain) at $85 \mathrm{kV}$ and $35.0 \mathrm{~mA}$ with an exposure time of 40 seconds, a voxel size of $200 \mathrm{~mm}$, a slice thickness of $2.0 \mathrm{~mm}$ and coupled to a Kodak Carestream 9000 3D ${ }^{\circledR}$ (Spain) software. The acquisition process was performed by an experienced radiologist according to the manufacturer's recommended protocol with the minimum exposure necessary for adequate image quality. The number of roots and root canals were determined in each tooth by moving the cursor to the Zaxis. The root canal configurations were assigned according to Vertucci's classification (Vertucci, 1984). Fan et al. (2008) categorization of the mandibular first premolars was used as reference for the $\mathrm{C}$-shaped canal configurations. The qualitative and quantitative features that characterized the root and root canals were observed and recorded. These were reported in an Excel ${ }^{\circledR}$ database, and the frequencies and statistical analyses were calculated (Statistica 7.0 StatSoft Ò).

\section{RESULTS}

The macroscopic analysis indicated 102 teeth with one root $(97.1 \%)$ and 3 with two roots $(2.9 \%)$. The CBCT

Table I. Root canal morphology of the mandibular first premolar according to Vertucci's classification and presence of C-shaped configuration.

\begin{tabular}{cccccc}
\hline Type of canal & Canal pattern & $\mathrm{N}$ & $\%$ & C-shaped & $\%$ \\
\hline I & 11 & 54 & 51.4 & 4 & 7.4 \\
III & 121 & 13 & 12.4 & 11 & 84.6 \\
V & 12 & 19 & 18.1 & 12 & 63.2 \\
VII & 1212 & 2 & 1.9 & 2 & 100.0 \\
Additional type & 12121 & 1 & 1.0 & 0 & 0.0 \\
& 13 & 1 & 1.0 & 1 & 100.0 \\
& 123 & 2 & 1.9 & 2 & 100.0 \\
& 1231 & 3 & 2.9 & 2 & 66.7 \\
& 1232 & 1 & 1.0 & 1 & 100.0 \\
& 12321 & 3 & 2.9 & 3 & 100.0 \\
& 1242 & 1 & 1.0 & 1 & 100.0 \\
2 ROOTS & 12324 & 1 & 1.0 & 1 & 100.0 \\
TOTAL & 123234 & 1 & 1.0 & 1 & 100.0 \\
& & 3 & 2.9 & 0 & 0.0 \\
& & 105 & 100.0 & 41 & 39.1 \\
\hline
\end{tabular}

Table II. Root canal distribution of C-shape according to Fan's et al. classification in mandibular first premolars.

\begin{tabular}{lcccccccc}
\hline & $\mathrm{C} 1$ & $\mathrm{C} 2$ & $\mathrm{C} 3$ & $\mathrm{C} 4 \mathrm{a}$ & $\mathrm{C} 4 \mathrm{~b}$ & $\mathrm{C} 4 \mathrm{c}$ & $\mathrm{C} 5$ & C6 \\
\hline cej & 0 & 0 & 0 & 1 & 2 & 38 & 0 & 0 \\
$2 / 3 \mathrm{rad}$ & 1 & 0 & 4 & 2 & 1 & 33 & 0 & 0 \\
$1 / 2 \mathrm{rad}$ & 6 & 1 & 20 & 0 & 1 & 13 & 0 & 0 \\
$1 / 3 \mathrm{rad}$ & 8 & 0 & 31 & 0 & 0 & 2 & 0 & 0 \\
at $2.5 \mathrm{~mm}$ apical & 3 & 1 & 33 & 1 & 0 & 3 & 0 & 0 \\
at $1 \mathrm{~mm}$ apical & 1 & 0 & 21 & 2 & 0 & 16 & 1 & 0 \\
\hline
\end{tabular}


Distribution of canal morphology by sex (Table III) indicates that both males and females present about $50 \%$ of Type I, and difference is not statistically significant (Chisquare $=.046,1$ d.f., $\mathrm{p}=.83$ ). Also the distribution of the remaining root morphology types (excluding Vertucci's Type I) does not reach the .05 thresholds (Chi-square 2.16, 3 d.f., $\mathrm{p}=.54$ ), despite females show higher frequencies of Type

Table III. Root canal distribution between males and females.

\begin{tabular}{|c|c|c|c|c|c|}
\hline Sex & Type & $\mathrm{N}$ & $\%$ & C-shaped & $\%$ \\
\hline \multirow{8}{*}{$\frac{\mathscr{J}}{3}$} & I & 18 & 52.9 & 2 & 11.1 \\
\hline & III & 2 & 5.9 & 2 & 100.0 \\
\hline & $\mathrm{V}$ & 7 & 20.6 & 4 & 57.1 \\
\hline & VII & 1 & 2.9 & 1 & 100.0 \\
\hline & IX & 4 & 11.8 & 4 & 100.0 \\
\hline & 2 ROOTS & 2 & 5.9 & 0 & 0.0 \\
\hline & TOTAL & 34 & 100.0 & 13 & 38.2 \\
\hline & Type & $\mathrm{N}$ & $\%$ & C-shaped & $\%$ \\
\hline \multirow{7}{*}{ 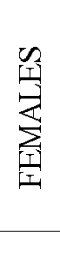 } & I & 36 & 50.7 & 2 & 5.6 \\
\hline & III & 11 & 15.5 & 9 & 81.8 \\
\hline & $\mathrm{V}$ & 12 & 16.9 & 8 & 66.7 \\
\hline & VII & 1 & 1.4 & 1 & 100.0 \\
\hline & Aditional types & 10 & 14.1 & 8 & 80.0 \\
\hline & 2 ROOTS & 1 & 1.4 & 0 & 0.0 \\
\hline & TOTAL & 71 & 100.0 & 28 & 39.4 \\
\hline
\end{tabular}

\section{DISCUSSION}

Several studies have focused on root and root canal morphology (Gu et al., 2013a; Singh \& Pawar, 2014; Sun et al., 2016; Cucina \& Navarro, 2016; Martins et al., 2017), but most did not consider the ethnic/genetic origin of the population. Root type and root canal morphology depend on the population's ethnicity, and it is critical to consider this feature for better root canal treatment (Trope et al., 1986).

The modern Maya population in the Yucatecan region (i.e., excluding the modern immigrants from foreign countries as well as from other states in Mexico) have a Mongoloid dental structure, but received Caucasoid and African influence during the last five centuries due to colonization (Cucina \& Navarro). While the majority of the traits have retained their original Mongoloid frequency of expression (Ramírez-Salomón et al., 2014; Cucina \& Navarro), others have changed as a response to such recent genetic admixture (Cucina \& Navarro).

In contrast to the majority of papers in the literature, the sample studied here is ethnically controlled-all teeth were from patients of known origin, sex, and age. The results indicate that $97.1 \%$ of the first mandibular premolars have
III. In terms of side (Table IV), the right one shows $31 \%$ Type I canals, vs $59.2 \%$ in the left side. Difference by side is statistically significant at the .05 thresholds (Chi-square $=6.67,1$ d.f., $\mathrm{p}=.0097)$. Also distribution of non-Type I canals presents differences between left and right teeth, but it is not statistically significant (Chi-square $=7.443,3$ d.f., $\mathrm{p}=.077)$.

Table IV. Root canal distribution between right and left side.

\begin{tabular}{|c|c|c|c|c|c|}
\hline Side & Type & $\mathrm{N}$ & $\%$ & C-shaped & $\%$ \\
\hline \multirow{8}{*}{ 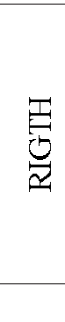 } & I & 9 & 31.0 & 2 & 22.2 \\
\hline & III & 2 & 6.9 & 1 & 50.0 \\
\hline & $\mathrm{V}$ & 10 & 34.5 & 7 & 70.0 \\
\hline & VII & 0 & 0.0 & 0 & 0.0 \\
\hline & Aditional types & 8 & 27.6 & 7 & 87.5 \\
\hline & 2 roots & 0 & 0.0 & 0 & 0.0 \\
\hline & TOTAL & 29 & 100.0 & 17 & 58.6 \\
\hline & Type & $\mathrm{N}$ & $\%$ & C-shaped & $\%$ \\
\hline \multirow{7}{*}{ 壱 } & I & 45 & 59.2 & 2 & 4.4 \\
\hline & III & 11 & 14.5 & 10 & 90.9 \\
\hline & $\mathrm{V}$ & 9 & 11.8 & 5 & 55.6 \\
\hline & VII & 2 & 2.6 & 2 & 100.0 \\
\hline & Aditional types & 6 & 7.9 & 5 & 83.3 \\
\hline & 2 roots & 3 & 3.9 & 0 & 0.0 \\
\hline & TOTAL & 76 & 100.0 & 24 & 31.6 \\
\hline
\end{tabular}

one root, and $2.9 \%$ were two-rooted. Such a distribution agrees with the literature from different populations worldwide, which shows that two-rooted mandibular first premolars are rare (Table II). Indeed, most populations have a frequency of single rooted premolars close to $100.0 \%$; only few are near $95.0 \%$.

Only Trope et al. reported frequencies of two-rooted mandibular first premolars that exceed those reported in all the other studies: $16.2 \%$ in an Afro-American sample. From an anthropological perspective, Scott \& Turner (1997) consider the two-rooted mandibular first premolar as Tomes' root. They state that the populations with higher occurrences worldwide are the Sub-Saharan Africans reaching a frequency as high as $38.0 \%$. This trait is common in Africans and Australian people. However, Tomes' root is reported as a trait characterized by varying degrees of expression in grooved roots. Only the maximum expression is a two-rooted tooth, according to Scott and Turner's standardized system. However, the frequencies they report also include a deep groove that runs continuously on both the mesial and distal surfaces of the root without creating two physically separated roots. Therefore, the frequencies 
VEGA-LIZAMA, E. M.; TIESLER, V.; CHI-KEB, J. R.; RAMÍREZ-SALOMÓN, M.; HERNÁNDEZ-MEJÍA, A. \& CUCINA, A. Root canal morphology of the mandibular first premolars in a Yucatecan population using cone beam computed tomography: An in vitro study. Int. J. Morphol., 36(4):1216-1221, 2018.

Table V. Number of roots in the mandibular first premolar worldwide.

\begin{tabular}{|c|c|c|c|c|c|c|}
\hline \multirow{2}{*}{ Author } & \multirow{2}{*}{ Group } & \multirow{2}{*}{ Country } & \multirow{2}{*}{ Sample size } & \multicolumn{3}{|c|}{ F requency $\%$} \\
\hline & & & & One root & Two roots & Three roots \\
\hline Vertucci (1984) & North Americans & USA & 400 & 100.0 & 0.0 & 0.0 \\
\hline Trope et al. (1986) & Euro-Americans & USA & 400 & 94.5 & 5.5 & 0.0 \\
\hline Trope et al. (1986) & Afro-Americans & USA & 400 & 83.8 & 16.2 & 0.0 \\
\hline Esponda (1994) & Latin-Americans & Mexico & - & $>95.0$ & - & 0.0 \\
\hline Sert and Bayirli (2004) & Caucasoids & Turkey & 200 & 100.0 & 0.0 & 0.0 \\
\hline Greco-Machado et al. (2009) & Europeans & Spain & 50 & 100.0 & 0.0 & 0.0 \\
\hline Khedmat et al. (2010) & Caucasoids & Iran & 217 & 100.0 & 0.0 & 0.0 \\
\hline Fan et al. (2012) & Asian & China & 327 & 100.0 & 0.0 & 0.0 \\
\hline Yang et al. (2013) & Asian & China & 440 & 99.3 & 0.7 & 0.0 \\
\hline Singh and Pawar (2014) & South Asian Indian & India & 100 & 94.0 & 6.0 & 0.0 \\
\hline Martins et al. (2017) & Caucasoids & Portugal & 1123 & 99.8 & 0.2 & 0.0 \\
\hline Pedemonte et al. (2017) & South - Americans & Chilean & 101 & 94.0 & 6.0 & 0.0 \\
\hline Pedemonte et al. (2017) & Caucasoids & Belgian & 100 & 100.0 & 0.0 & 0.0 \\
\hline
\end{tabular}

reported by Scott \& Turner clearly overestimate the real frequency of two-rooted mandibular first premolars. Nonetheless, we can still infer that two-rooted mandibular first premolars are more frequent in these two populations, which largely confirms the values reported for AfroAmericans by Trope et al.

The evolutionary characteristic of the mandibular first premolar is single-rooted in most human populations. The frequency of $97.1 \%$ in the modern Yucatecan sample is consistent with this evolutionary process and with the (potential) European genetic influence. The frequencies are similar to populations in northeastern Asia (Table V). In contrast, the influence of African people is not sufficiently strong to affect the morphological structure of the tooth. This frequency concurs with Esponda (1994) who encountered more than $95.0 \%$ single rooted mandibular first premolars in a Mexican population and whose genetic history is very similar to that of the sample under study.

With regards to root canal configuration, all previous studies report that the most common feature in mandibular first premolars is one root canal (Vertucci's Type I). As our results also indicate, this aspect is not related to the sex of the individual; however, the comparison between left and right sides indicate a significant prevalence of Type I in the former. Despite sample size can be a factor in this difference, further analyses and larger comparative samples are necessary.

In general, the frequencies of Type I are very variable worldwide, ranging from $53.7 \%$ to $88.5 \%$ (Vertucci; Trope et al.; Sert \& Bayirli, 2004; Lu et al., 2006; GrecoMachado et al., 2009; Liu et al., 2013; Yang et al., 2013; Singh \& Pawar; Chen et al., 2014; Sun et al.; Martins et al.; Pedemonte et al., 2017). Caucasoid (European) populations had the highest frequencies (Trope et al.; Khedmat et al.,
2010; Pedemonte et al.), and Asian populations had the lowest (Liu et al.; Sun et al.). This study shows that the Yucatecan population falls well within the range of variability of Asian populations-51.4\% were Vertucci's Type I. This also indicates that the Asian populations (including the Yucatecan one) are characterized by a higher degree of variability in terms of internal root canals' morphology.

The results indicate that Vertucci's Type V was the second most frequent morphology $(18.1 \%)$ similar to other studies that presented frequencies of $9.3 \%$ to $25.6 \%$ (Vertucci; Lu et al.; Greco-Machado et al., 2009; Liu et al.; Yang et al.; Chen et al.; Sun et al.; Martins et al.; Pedemonte et al.). Only Singh \& Pawar and Sert \& Bayirli reported second higher frequencies of Type IV $(10.0 \%)$ and Type II $(18.5 \%)$ in patients from India and Turkey, respectively. Based on this variability and on the frequencies of root canals not corresponding to Type I, it is clearly important to understand the ethnic origin of the patient.

This investigation shows that the modern Maya population has higher frequencies of $\mathrm{C}$-shape in the mandibular first premolars $(39.1 \%)$ in comparison with the values reported in the literature, which range between $1.1 \%$ (Yang et al) and 29.7\% (Fan et al. 2012). Yang et al. reported a $1.1 \%$ frequency in a Chinese population-these low values are common in Caucasian populations. The high frequencies seen in the literature were also seen in Asian populations (Lu et al.; Fan et al., 2008; Khedmat et al.; Fan et al., 2012; Yang et al.; Gu et al., 2013a,b). The C-shape pattern in premolars concurs with the same morphology recorded in the mandibular second molars, which showed frequencies above $30 \%$ in Prehispanic and modern Maya (RamírezSalomón et al. 2014), Chinese (Zheng et al., 2011), and Korean (Jin et al. 2006) populations: $35.0 \%$ in Maya and Yucatecans, $38.6 \%$ in Chinese, and $44.6 \%$ among Koreans. 
VEGA-LIZAMA, E. M.; TIESLER, V.; CHI-KEB, J. R.; RAMíREZ-SALOMÓN, M.; HERNÁNDEZ-MEJÍA, A. \& CUCINA, A. Root canal morphology of the mandibular first premolars in a Yucatecan population using cone beam computed tomography: An in vitro study. Int. J. Morphol., 36(4):1216-1221, 2018.

Most of the literature on the mandibular first premolars reports one canal in the root's cervical portion, while the C-ribbon is located in the medial and apical thirds of the root (Fan et al., 2008; Khedmat et al.; Fan et al., 2012; Gu et al., 2013a,b; Liu et al.; Ordinola-Zapata et al., 2015). This pattern is different from mandibular second molars in which the C-ribbon can already be observed in the root's cervical third (Hargreaves \& Berman).

The mandibular premolars' C-ribbon pattern-in which the C-shape cannot be appreciated in the root's cervical portion-makes its identification and endodontic intervention more difficult. It somewhat decreases the success of treatment-especially in the presence of chronic pathological conditions. Higher frequencies of C3 canals were found in Asian populations (Lu et al.; Fan et al., 2008) except for C1 and C2 types reported by Gu et al. (2013a,b). Khedmat et al. described a Caucasian population from Iran and reported that $\mathrm{C} 3$ is the most common type, while an analysis of a Brazilian population indicated the $\mathrm{C} 1$ and $\mathrm{C} 2$ types in the medial and apical thirds of the roots are the most common (Ordinola-Zapata et al.).

European populations have a groove along the premolars' roots whose frequencies range between $1.4 \%$ (Khedmat et al.) and $10.9 \%$ (Martins et al.). Such frequencies instead range between $24.0 \%$ (Fan et al. 2008) and $56.2 \%$ (Gu et al. 2013a) in Asiatic populations. Again, the frequencies in Asian groups are consistent with the results of our study. Several papers report that $100.0 \%$ of the C-ribbon was found in mandibular first premolars with groove, indicating a correlation between the presence of the groove and the Cribbon similar to our findings (Lu et al.; Fan et al., 2008; Khedmat et al.; Fan et al., 2012). The exceptions to this pattern were the studies by Fan et al. (2012), Ordinola-Zapata et al. and Martins et al., who reported C-shape ribbon respectively in $66.2 \%, 67.5 \%$, and $21.3 \%$ of the teeth with an external groove. The location of the groove in the Yucatecan population was mesiolingual, which is consistent with the evidence found in other studies (Fan et al., 2008; Gu et al., 2013a; Liu et al.; Martins et al.); nonetheless, lingual and mesial main positions were reported by Lu et al. and Chen et al. respectively.

\section{CONCLUSION}

Overall, half of the sample presented one root canal along the whole length of the root; the other half was very variable. Most variations in first mandibular premolar in this Maya population had a C-shaped configuration, had more than one root canal, and were located from the middle to the apical portion of the root.
The ethnic origin of the Yucatecan population is SinoAmerican from northeastern Asia. The C-shaped first premolar is very common in this group; our results confirm the similarities with the Asian populations and agree with the endodontic and anthropological literature. Knowledge of root canal configuration is a basic requirement for practitioners for a successful endodontic treatment. Whereas available, computed tomography should be used in all cases when needed. Further studies should analyze more detailed measures, and the $\mathrm{C}$-shaped configurations in diverse populations should be analyzed according to ethnic background.

\section{ACKNOWLEDGEMENTS}

We are grateful to to Gabriel Alvarado Cárdenas and Hector Rubio Zapata of the UADY for their invaluable contributions to this research, as well as to Fernando Aguilar Ayala, Ruben Herrera Atoche and Mauricio Escoffié Ramirez, current Dean and authorities of the School of Dentistry (UADY) for facilitating the investigation. This research was financed by the Mexican Secretary of Public Education (PROMEP) UADY-PTC-225 to E.M.V.L., CONACYT Project-CB-152105 to V.T. and CONACYT Project-CB-154750 to A.C. The authors report no fees or financial arrangements paid to consultants or other investigations and have nothing to disclose. The authors deny any conflicts of interest related to this study.

VEGA-LIZAMA, E. M.; TIESLER, V.; CHI-KEB, J. R.; RAMÍREZ-SALOMÓN, M.; HERNÁNDEZ-MEJÍA, A. \& CUCINA, A. Morfología del conducto radicular de primeros premolares mandibulares en una población Yucateca usando tomografía computarizada: Estudio in vitro. Int. J. Morphol., 36(4):1216-1221, 2018.

RESUMEN: El éxito en el tratamiento endodóntico requiere el conocimiento profundo de la configuración interna del sistema de conductos radiculares. La mayoría de las personas que viven en Yucatán son de origen Maya y poseen el patron dental Mongoloide; por lo tanto, se esperan variaciones debido a su etnicidad. El propósito de esta investigación fue evaluar las características morfológicas y la variabilidad del conducto radicular en la población yucateca. Se analizaron ciento cinco primeros premolars mandibulares extraídos de pacientes provenientes de una muestra Maya mexicana; la muestra fue obtenida de la Clínica de Cirugía Oral de la Facultad de Odontología de la Universidad Autónoma de Yucatán. Con consentimiendo informado escrito. Se utilizaron Tomografías Computarizadas para el análisis de la muestra. La configuración más prevalente fue la Tipo I de Vertucci con $51,4 \%$. Sin embargo, 41 de 105 casos $(39,1 \%)$ presentaron un surco radicular y la configuración en forma de "C". Se documen- 
taron casos con 1, 2, 3 y 4 conductos radiculares. Los primeros premolares mandibulares de la población Yucateca son muy variables. La variabilidad y frecuencia de conductos en forma de "C" concuerda con estudios realizados en segundos molars mandibulares en esta zona confirmando la importancia del origen étnico de las poblaciones para los tratamientos endodónticos.

KEY WORDS: Conducto en forma de "C"; Primeros premolars mandibulares; Conducto radicular.

\section{REFERENCES}

Chen, J.; Li, X.; Su, Y.; Zhang, D.; Wen, X.; Nie, X.; An, J.; Liu, L. \& Deng, M. A micro-computed tomography study of the relationship between radicular grooves and root canal morphology in mandibular first premolars. Clin. Oral Invest., 19(2):329-34, 2014.

Cucina, A. \& Navarro Cornejo, A. La evolución de la morfología dental en el norte de Yucatán: de lo prehispánico a lo moderno. Estud. Antropol. Biol., 18(1):31-46, 2016.

Esponda, R. Anatomía Dental. Ciudad de México, Universidad Nacional Autónoma de México, 1994.

Fan, B.; Yang, J.; Gutmann, J. L. \& Fan, M. Root canal systems in mandibular first premolars with C-shaped root configurations. Part I: Microcomputed tomography mapping of the radicular groove and associated root canal cross-sections. J. Endod., 34(11):1337-41, 2008.

Fan, B.; Ye, W.; Xie, E.; Wu, H. \& Gutmann, J. L. Three-dimensional morphological analysis of C-shaped canals in mandibular first premolars in a Chinese population. Int. Endod. J., 45(11):1035-41, 2012.

Greco-Machado, Y.; García-Molina, J. A.; Lozano-De-Luaces, V. \& Manzanares-Céspedes, M. C. Morfología de los conductos radiculares de premolares superiores e inferiores. Endodoncia, 27(1):13-18, 2009.

Gu, Y. C.; Zhang, Y. P.; Liao, Z. G. \& Fei, X. D. A micro-computed tomographic analysis of wall thickness of C-shaped canals in mandibular first premolars. J. Endod., 39(8):973-6, 2013a.

Gu, Y.; Zhang, Y. \& Liao, Z. Root and canal morphology of mandibular first premolars with radicular grooves. Arch. Oral Biol., 58(11):1609$17,2013 \mathrm{~b}$.

Hargreaves, K. M. \& Berman, L. H. Cohen's Pathways of the Pulp. $11^{\text {th }} \mathrm{ed}$. St. Louis, Elsevier, 2016.

Jin, G. C.; Lee, S. J. \& Roh, B. D. Anatomical study of C-shaped canals in mandibular second molars by analysis of computed tomography. $J$. Endod., 32(1):10-3, 2006.

Khedmat, S.; Assadian, H. \& Saravani, A. A. Root canal morphology of the mandibular first premolars in an Iranian population using crosssections and radiography. J. Endod., 36(2):214-7, 2010.

Liu, N.; Li, X.; Liu, N.; Ye, L.; An, J.; Nie, X.; Liu, L. \& Deng, M. A microcomputed tomography study of the root canal morphology of the mandibular first premolar in a population from southwestern China. Clin. Oral Invest., 17(3):999-1007, 2013.

Lu, T. Y.; Yang, S. F. \& Pai, S. F. Complicated root canal morphology of mandibular first premolar in a Chinese population using the cross section method. J. Endod., 32(10):932-6, 2006.

Martins, J. N. R.; Francisco, H. \& Ordinola-Zapata, R. Prevalence of Cshaped configurations in the mandibular first and second premolars: A cone-beam computed tomographic in vivo study. J. Endod., 43(6):8905, 2017.

Ordinola-Zapata, R.; Monteiro Bramante, C.; Gagliardi Minotti, P.; Cavalini Cavenago, B.; Gutmann, J. L.; Moldauer, B. I.; Versiani, M. A. \& Hungaro Duarte, M. A. Micro-CT evaluation of C-shaped mandibular first premolars in a Brazilian subpopulation. Int. Endod. J., 48(8):80713,2015
Pedemonte, E.; Cabrera, C.; Torres, A.; Jacobs, R.; Harnisch, A.; Ramírez, V.; Concha, G.; Briner, A. \& Brizuela, C. Root and canal morphology of mandibular premolars using cone-beam computed tomography in a Chilean and Belgian subpopulation: a cross-sectional study. Oral Radiol., 34(2):143-50, 2018.

Ramírez-Salomón, M.; Vega-Lizama, E.; Tiesler, V.; Alvarado-Cárdenas, G.; López-Villanueva, M.; Sierra-Sosa, T. \& Cucina, A. The C-shaped canal molar: an Endodontic-Archaeological study of the relationships between Mayan pre-Hispanic and contemporary population of Yucatán. Int. Endod. J., 47(11):1084-9, 2014.

Scott, R. \& Turner, C. The Anthropology of Modern Human Teeth. New York, Cambridge University Press, 1997.

Sert, S. \& Bayirli, G. S. Evaluation of the root canal configurations of the mandibular and maxillary permanent teeth by gender in the Turkish population. J. Endod., 30(6):391-8, 2004.

Singh, S. \& Pawar, M. Root canal morphology of South asian Indian mandibular premolar teeth. J. Endod., 40(9):1338-41, 2014.

Sun, Y.; Lu. T. Y.; Chen, Y. C. \& Yang, S. F. The best radiographic method for determining root canal morphology in mandibular first premolars: A study of Chinese descendants in Taiwan. J. Dent. Sci., 11(2):175-81, 2016.

Trope, M.; Elfenbein, L. \& Tronstad, L. Mandibular premolars with more than one root canal in different race groups. J. Endod., 12(8):343-5, 1986.

Vertucci, F. J. Root canal anatomy of the human permanent teeth. Oral Surg. Oral Med. Oral Pathol., 58(5):589-99, 1984.

Yang, H.; Tian, C.; Li, G.; Yang, L.; Han, X. \& Wang, Y. A cone-beam computed tomography study of the root canal morphology of mandibular first premolars and the location of root canal orifices and apical foramina in a Chinese subpopulation. J. Endod., 39(4):435-8, 2013.

Zheng, Q.; Zhang, L.; Zhou, X.; Wang, Q.; Wang, Y.; Tang, L.; Song, F. \& Huang, D. C-shaped root canal system in mandibular second molars in a Chinese population evaluated by cone-beam computed tomography. Int. Endod. J., 44(9):857-62, 2011.

\section{Corresponding author:}

Elma María Vega-Lizama

Calle 44A No. 232 por 23 y 25

Col. Roma

C.P. 97218. Mérida

Yucatán

MÉXICO

\section{Email: elma.vega@correo.uady.mx}

Received: 02-05-2018

Accepted: 26-07-2018 